\title{
Île De La Passion in the Transpacific Framework
}

\author{
José Ernesto Rangel Delgado \\ Universidad de Colima, Las Víboras, México \\ Email: erangel@ucol.mx
}

How to cite this paper: Rangel Delgado, J. E. (2019). Île De La Passion in the Transpacific Framework. Advances in Historical Studies, 8, 91-98.

https://doi.org/10.4236/ahs.2019.82006

Received: February 1, 2019

Accepted: March 25, 2019

Published: March 28, 2019

Copyright $\odot 2019$ by author(s) and Scientific Research Publishing Inc. This work is licensed under the Creative Commons Attribution International License (CC BY 4.0).

http://creativecommons.org/licenses/by/4.0/

\begin{abstract}
Transpacific relations (RT, for its acronym in Spanish) as a construct for the analysis of the most active economic region of the 21st century, represent an analytical instrument that has been shaped to improve knowledge of the $\mathrm{Pa}$ cific Basin. In the present article, geo-economics as well as geopolitical aspects of insular order are incorporated. Neocolonialism, national security, exploitation of natural resources with respect for the environment, supported in historical facts, are concepts that are added to strengthen the knowledge of RT in general by taking as a reference the multi-named Medanos Island-Clipperton Island- Île de la Passion, located to $10^{\circ} 17^{\prime} 38^{\prime \prime} \mathrm{N} / 109^{\circ} 13^{\prime} 02^{\prime \prime} \mathrm{W}$, geographically belonging to the Revillagigedo Islands, Colima, Mexico, but under French ownership.
\end{abstract}

\section{Keywords}

National Security, Colonialism, Neocolonialism, Transpacific Relations, Trade, Economy, History, Geography

\section{Introduction}

Going back to the theme of the Île de la Passion/Clipperton Island or also known in its first discovery as Médanos Island, is not a minor issue, particularly considering that around what has already been written are aspects of economy, trade, history and geography, as well as national security, colonialism and island neocolonialism in the Pacific Basin, not properly commented, taking into account the transpacific relations.

Although writings and research have been carried out, which have led to journalistic and historical products (González Avelar, 1992), even novelists (Arnaud, 1982; Restrepo, 2005; Bergua García, 2007), it is worth highlighting, to contextualize the transpacific relations of the XXI century, that maritime commercial route of the XVI century crossed by the Nao of China between Manila 
(The Philippines) and Acapulco (Mexico), connecting Asia with Latin America.

According to Romero Giordano, 2003; Calvo \& Machuca, 2016, as early as 1565 , the Nao of China, traveled a maritime route through which circulated valuable goods of his time such as spices, silks, porcelains, exotic perfumes, giant pearls and gunpowder, which incidentally was an attractive booty for lurking English buccaneers, as was the case with the pirate John Clipperton.

Some critical claims until today, as the case of the Kuril Islands (between Russia and Japan), the Spratley Islands (between Malaysia, The Philippines, Vietnam, Mainland China, Taiwan and Brunei), the Dokdo/Takeshima Islands (between South Korea and Japan, give us geopolitical, geoceconomic and nationalist insular disputes, similar to the Île De La Passión Island located on the Mexican South Pacific coast.

To these sets of disputes, is added that of the Île de la Passion/Clipperton Island, located off the coast of the South Pacific of Mexico, according to United Nation colonialism resolution helping to the Public Policies design for development in Mexico.

The island is a coral atoll, currently uninhabited with $5 \mathrm{~km}^{2}$ of surface and 11 $\mathrm{km}$ of coastline. It is currently a European possession managed from French Polynesia by a high commissioner of France, which places it in the context of a geoeconomic and geopolitical space of transpacific relations that opens the possibility of asking itself if there are sufficient economic and/or defense interests in around the island, or perhaps its possession represents only an unjustified nationalist sentiment.

There are several economic and trade factors but strategic as national security, claim of the maritime extension and, the marine resources in the sphere of influence as well, to rethink the presence of Mexico in the Asia Pacific region arising a very important issue to strengthen the studies of transpacific relations as theoretical framework.

\section{Brief History}

The XV and XVI centuries were characterized by expeditions that led to the incorporation of Latin America into the European world economy. Powers such as Spain, England and France, among others, launched to the discovery of overseas territories of which they appropriated. This is the case of some islands located in the Pacific Ocean, which in the XXI century continue under its administration.

The island territory located at $10^{\circ} 17^{\prime} 38^{\prime \prime} \mathrm{N} / 109^{\circ} 13^{\prime} 02^{\prime \prime} \mathrm{W}$ was initially discovered by Alvaro de Saavedra Ceron, during the trip he made in November 1526 to reach the Moluco, giving it the name of Médanos Island, leaving it since then, under the administration of New Spain (González Avelar, 1992).

In search of places to take refuge along the Pacific Ocean, the English pirate John Clipperton, visited the island in February 1705. Clipperton managed to make clear the possession of the island to the English crown interested in the large quantities of guano, rich in phosphate. However, in 1711 France, redisco- 
vered the island, assigned it the name Île de la Passion (Island of the Passion) and claimed it as national property for the European country.

The cartography of the sixteenth century clearly shows the initial Spanish dominion. In such a way that, after the war of 1810 with Spain, the island becomes part of the territories of Mexico, according to its declaration of independence of 1821. Subsequently, the Mexican constitutions of 1824 and 1857 explicitly included the territory in question, however, it was later excluded from the 1917 Constitution, for various reasons.

A dispute was raised around the real property of the Island managed by Victor Emmanuel III of Italy (supported by the Vatican), granted France the sovereignty of the island in 1931 .

With all this, for decades until today nobody had settled permanently on the island.

\section{Geography}

The Île de la Passion, belongs geographically to the Revillagigedo Islands and is located $900 \mathrm{~km}$ from Isla Socorro, Colima ${ }^{1}$, México, with very limited vegetation. It is an island that has $5 \mathrm{~km}^{2}$ of surface (to give us an idea of its size, Isla $\mathrm{Mu}$ jeres, $\mathrm{QR}$, Mexico measures $4 \mathrm{Km}^{2}$ ). Due to the ring shape of the island, its interior lagoon has been closed for approximately a century. The water in the lagoon is acidic and is supposed to be what remains of a volcano, a habitat for inedible fish. Its elevation above sea level is not more than 2 meters high, highlighting a small promontory of 29 meters in the southeast known as Clipperton Rock, which at the time was considered the best place to build a lighthouse.

It is the only atoll of its kind in the eastern Pacific, since this type of atoll is more common in the South Pacific, near New Zealand, which gives it specific characteristics that have led to various strategic projects. It is home to various types of birds and crabs.

Between May and October, the Île de la Passion receives a high solar radiation that is little reduced throughout the year. Cyclones and tropical storms constantly attack it, especially in the rainy season, which starts approximately in June and ends in November. Its annual pluvial precipitation is of the order of $5000 \mathrm{~mm}$, which supplies it with water for human consumption.

Before being rediscovered by the French, the island was covered by undergrowth, with some palm trees. It is believed that the weeds of the island disappeared between 1858 and 1917. Hypothetically, the vegetation of the island was decimated by a tropical storm and an earthquake accompanied by tsunami and was not able to regenerate due to the large number of land crabs that like that flora.

After the introduction of pigs by the guano gatherers, the flora of the island was regenerated by the taste they developed for the land crabs. During the set-

${ }^{1}$ The United Nations Convention on the Law of the Sea of 1982 establishes 12 nautical miles $(22.2$ $\mathrm{km}$ ), as territorial sea, understood as the sector of the ocean in which a State exercises full sovereignty. 
tlement period, the vegetation of the island multiplied with the introduction of the coconut palm tree in the last decade of the $19^{\text {th }}$ century, by the German Gustavo Schultz, who moved them from the Islas Socorro (González Avelar, 1992).

The large amount of guano product of the fauna existing on the island, proved to be sufficient reason to arouse the interest of economic powers to be rich in nitrogen, phosphorus and potassium, which even today, continues to be appreciated for organic agriculture. Particularly at that time, the guano played a fundamental role in the development of agricultural practices and led to the formal colonization of the island, representing an economic potential coupled with the variety of marine resources between the island and the mainland.

\section{On Colonialism/Neocolonialism and the Île De La Passion}

The Ile de la Passion is located in the context of forms of colonialism still existing throughout the Pacific Ocean. As already mentioned, it is administered by French Polynesia intermediating a little less than 3,354miles.

The colonialization of spaces beyond the power's borders finds its explanation in the expansion of capital supported by trade. It is precisely in the Pacific Ocean that there are still places as Micronesia (the Marshall Islands, the Federated States of Micronesia, the Northern Marianas, Belau/Guam), and Eastern Samoa, under North American control; Kanaky (New Caledonia), Wallis and Futuna, and Polynesia, under French control, that continue with the reproduction of a colonial pattern. So, the Île de la Passion extents the fact that the "Pacific Basin", and therefore the "transpacific relations", in perspective, places the struggle for power and the differences between France and Mexico, with the reformulation of the asymmetric relations of power.

In such a way that transpacific relations, acquire meaning if they are understood in relation to a set of social formations associated with the former metropolises and colonial metropolises. These social formations manifested in non-dominant economies of the Pacific (as would be the case of Mexico), have a specific presence in the global context of the region, which needs to be considered beyond trade. To these we should add alleged "racial relations", "territorial size", "cultural simplicity" and "primitivism" that require the support of "civilized" Western economies, against to United Nations that considers the independence of the colonial countries (Devalle, 1989; González Avelar, 1992).

It is so Mexican government, and Mexican federal states involved, have to return to the Ile de la Passion to increase its island's natural resources, those of its surroundings on the seabed (minerals), research and protect the natural heritage submerged in its reef and freely exploiting the fishing resources of its immediate waters. In such a way that it is possible to extend its territorial sea and its rights of navigation, overflight, fishing, marine scientific research, mining discoveries on the seabed and the protection of the marine environment; that is, economic and political rights that would grant Mexico a greater presence in the Pacific Basin and, therefore, in transpacific relations, vanishing the colonial/neocolonial 
sense that has historically characterized it.

\section{Transpacific Relations and the Île De La Passion}

González Avelar (1992) convincingly mentions the trans-Pacific sense of Clipperton, referring to the 250-year tour of the Nao of China. It also makes clear that "... the dispute over the sovereignty of the...Île de la Passion... brought Mexico out of its lethargy, in terms of its island policy... in the Pacific... it refers, above all because it implied the loss of territories inherited from Spain, propitiating the mood to explore widely... the... possibilities and resources... susceptible of being incorporated... to the development for the benefit of the Mexicans".

Another aspect to consider transpacific order is that, although in the beginning French interest in the Ile de la Passion dates back to the mid-nineteenth century, when Napoleon III decided to seize the island to exploit phosphate in their guano deposits, later he made clear its geo-economics and geopolitical character, for the construction of an interoceanic canal (later the Panama Canal), giving the Ile de la Passion greater importance.

However, the emperor did not find out if the island belonged to any nation and on November 22, 1858 Lieutenant of the ship L'Amiral, Víctor Le Coat De Kerweguen, took an act of taking possession on the deck of the ship, from where he observed that territory, because he could not land it (González Avelar, 1992).

We have commented above that both the concept of "Pacific Basin" and "transpacific relations" are closely related to power struggles by specific powers. This is the case of France in the region, but it has also been the case of others such as the Netherlands, Japan, the United States, Russia, the United Kingdom and China.

So that, in our opinion, transpacific relations should be observed in two areas: the one that considers economic relations, typical of the transfer of value from the periphery to the center, and the one that brings economic relations closer to the dynamics of International Trade-Globalization, seeking an explanation to the different concepts associated with the global, international and global, when commercial relations are concerned, as is the case of the route between Manila and Acapulco and its heritage in the imaginary of the Pacific Basin (Rangel Delgado \& Max Monroy, 2017).

The Île de la Passion shows geographical location that is an input for the interpretation and reinterpretation of transpacific relations. That fact that it is located very close to the coasts of the South Pacific of Mexico is relevant for the protection of its national security.

Thus, commerce (due to the abundance of guano and other marine resources $)^{2}$, strategic location, flora and fauna of the island, and even the potential of tourism has suggested that the island could have its own infrastructure (with an airport and a fishing port in the lagoon, for example); which would imply attractive investments.

In that same order of ideas, it has been commented to convert the Ille de la 
Passion into an oceanographic observatory ${ }^{3}$, in such a way that the conflict between France and Mexico could even be ended. In this regard, Mexican, American and Australian researchers agree, in such a way that they jointly carried out an expedition staying on the island for more than four months.

Mexican researchers Francisco Solís, Margarita Merino Salazar and Carlos González, found new species of organisms that serve as indicators on marine pollution, representing an ecological importance in food chains and biodiversity with an impact on human life. They stated that, even with a reduced diversity, the existing diversity is abundant and that the environment surrounding the island is not contaminated. Likewise, they have left reference to the fact that the position of the ports of Manzanillo and Acapulco represents the closest departure point of our territory to the island (Habana De Los Santos, Misael, 2005).

Factors of another order nuance transpacific relations, namely: the nuclear tests that have often been carried out in the Ocean Pacific, the existence of military bases and strategic control; the transport and disposal of harmful substances that affect the environment; the introduction of exogenous species as part of development plans recommended by international agencies, with negative biological and socioeconomic effects; the effects of the tourism industry; and the massive introduction of foreign capital and products (Shand, 1980).

Certainly, some authors have considered that transpacific relations are oriented by the chain of organizations that seek to order, in a multilateral manner, the set of relationships existing in the region, as is the case of the Pacific Basin Economic Cooperation (PBEC), the Pacific Economic Cooperation Council (PECC), the Asia Pacific Economic Cooperation (APEC) the Latin America East Asia Cooperation Forum (FOCALAE, for its acronym in Spanish), the Pacific Trade and Development Conference (PAFTAD), among others, in such a way that, in other words, transpacificidad (Uscanga, 2005; Ramírez Meda, 2015) goes beyond of commercial relations to better interpret Mexico in the context of the Pacific Basin and the power struggles it implies (Devalle, 1989). In addition to issues beyond multilateral economic cooperation, such as those related to the participation of civil society (Velarde, 2011), they show that transpacific relations also have to deal with other issues, such as national security or marine affairs; topics of our interest in this article.

In that sea of links between the countries located around the Pacific Ocean, we imagine the Île de la Passion. Above all, because it implies a greater meaning of the most active insertion of Mexico to modern conceptualization of the Pacific Basin and transpacific relations.

However, despite the fact that France holds its property, today, the island has been abandoned since the end of the Second World War and has only been vi${ }^{2}$ Despite the fact that 115 commercial species have been identified in the territorial waters of the island, tuna has been the only one exploited. Outside of fishing on the island, no other exploitable natural resource has been discovered. The atoll has been occupied several times by guano miners, military personnel, usually from Mexico.

${ }^{3}$ As have been the foundations in Antarctica that successfully coexist various countries and maintain their bases there for scientific purposes. 
sited by sports fishermen, French Navy patrols and Mexican fishermen, leaving open the possibility of considering it again in the context of complex transpacific relations that affect Mexico.

\section{Conclusion}

This article considers the commercial route established by the Nao of China as a concrete expression, which precedes the transpacific relations that are expressed in the $21^{\text {st }}$ century. The route of Nao de China involved in its journey to the Isle of Médanos, later known as Clipperton Island and Île de la Passion.

Likewise, it is proposed to consider the interests of France in the Île de la Passion, with administration in French Polynesia preceded by the geostrategic and geo-economics sense of the opening of the Panama Canal, to reduce trade times between the Pacific Ocean and the Atlantic Ocean, giving meaning to the transpacific relations intermediating around 3354 miles, vs. just 560 miles approx. from the Islas Socorro belonging to Colima, which brings it closer to the interests of Mexico.

Another of the elements that could be considered for enriching the transpacific relations knowledge is that related to the colonialism/neocolonialism, from the United Nations point of view. Due to its geographical location, its history and legal international status, close to Mexico, the lle de la Passion has not to be considered like a colony; on the contrary, it has a potential national security sense and other strategic linkages in the Pacific Basin.

It is certainly possible to imagine the Île de la Passion not only as an economic option, but also as a space for international cooperation, in its broadest sense, to promote the protection of the environment, giving opportunity for alternative interpretations to the occidental centric historically imposed in the Pacific Basin.

Therefore, the context of transpacific relations represents a scenario that has to consider not only trade and investments, but also geopolitical and geo-economic aspects to give access, in addition, to the consideration of natural and cultural resources that are intertwined in a complex, multi-faceted, transpacific environment, insular, which points to the better functioning of the regional order of the new and complex Pacific Basin order.

\section{Conflicts of Interest}

The author declares no conflicts of interest regarding the publication of this paper.

\section{References}

Arnaud, M. T. (1982). La tragedia de Clipperton. México: Ed. Arguz.

Bergua García, A. (2007). Isla de bobos. México: Seix Barral, colección Breve.

Calvo, T., \& Machuca, P., Editores. (2016). México y Filipinas: Culturas y memorias sobre el Pacífico. El Colegio de Michoacán, Ateneo de Manila University.

Devalle, S. B. C. (1989). Bastiones Coloniales en el Pacífico Actual: Kanaky (Nueva 
Caledonia).

https://estudiosdeasiayafricaa.colmex.mx/index.php/eaa/article/download/1083/1083

González Avelar, M. (1992). Clipperton, isla mexicana. México: Fondo de Cultura Económica.

Habana De Los Santos, Misael (2005). http://noticias.universia.net.mx/ciencia-nn-tt/noticia/2005/04/19/97957/proponen-con vertir-clipperton-observatorio-oceanografico.html

Ramírez Meda, K. M. (2015). Esquemas de Inversión Sectorial Energética Sino-rusa y sus Implicaciones Transpacíficas: Los Casos de México y Ecuador. Tesis de Doctorado en Relaciones Transpacíficas. México: Universidad de Colima.

Rangel Delgado, J. E., \& Max Monroy, E. E. (2017). Lo "Mundial”, lo "Internacional” y lo “Global” en las Relaciones Transpacíficas. Orientando, 14, No. 7.

Restrepo, L. (2005). La Isla de la Pasión. México: Alfaguara.

Romero Giordano, C. (2003). Breve Historia de la Nao de Manila. Mexico desconocido. http://acapulco.com/es/artman/publish/printer_35.html

Shand, R. T. (1980). The Island States of the Pacific and Indian Oceans: Anatomy of Development. Canberra: ANU Press (Development Studies Centre Monograph 23). https://openresearch-repository.anu.edu.au/bitstream/1885/131347/1/DSC_monograp h_23.pdf

Uscanga, C. (2005). Transpacificidad, una agenda pendiente para los contactos de América Latina con el Pacífico. En Jaramillo G. (comp.) Los nuevos enfoques de la integración: más allá del nuevo regionalismo. Ecuador: Flacso.

Velarde, S. F. (2011). La sociedad civil surcoreana en su construcción democrática y ciudadana: entre los valores confucianos y occidentales: la perspectiva con México 1985-2010. Tesis de Doctorado en Relaciones Internacionales Transpacíficas. México: Universidad de Colima. 